\title{
LA (IM)POSIBILIDAD DE LA ADAPTACIÓN: LA RELACIÓN ENTRE EL CINE Y EL TEXTO ESCRITO PARA REPRESENTAR LO BOLIVIANO
}

\section{Andrés Laguna Tapia}

\section{RESUMEN}

Desde sus comienzos, el cine tiene una relación fuerte con la literatura. La tradición fílmica boliviana no es una excepción. Este artículo reflexiona en torno a ella y ante las (im)posibilidades de la adaptación, a partir de algunos conceptos e ideas de autores como Gerard Genette, Robert Stam o Jacques Derrida. Además, busca develar si esta relación ha sido afectada por su contexto sociohistórico y como ha contribuido a la construcción de una representación nacional. Revisando obras emblemáticas del cine boliviano como Wara Wara, Jonás y la ballena rosada, American visa y Los viejos, se problematiza la importancia de la adaptación cinematográfica para la construcción de sujetos nacionales.

Palabras clave: Cine boliviano, literatura boliviana, adaptación cinematográfica, sujeto nacional, representación nacional.

DOI: $10.23881 /$ idupbo.017.2-6e 